We are grateful to Mr D. O. Brown and Dr J. R. W. Govan for their interest and support during this work which was made possible by a grant from the Scottish Hospital Endowments Research Trust.

\title{
REFERENCES
}

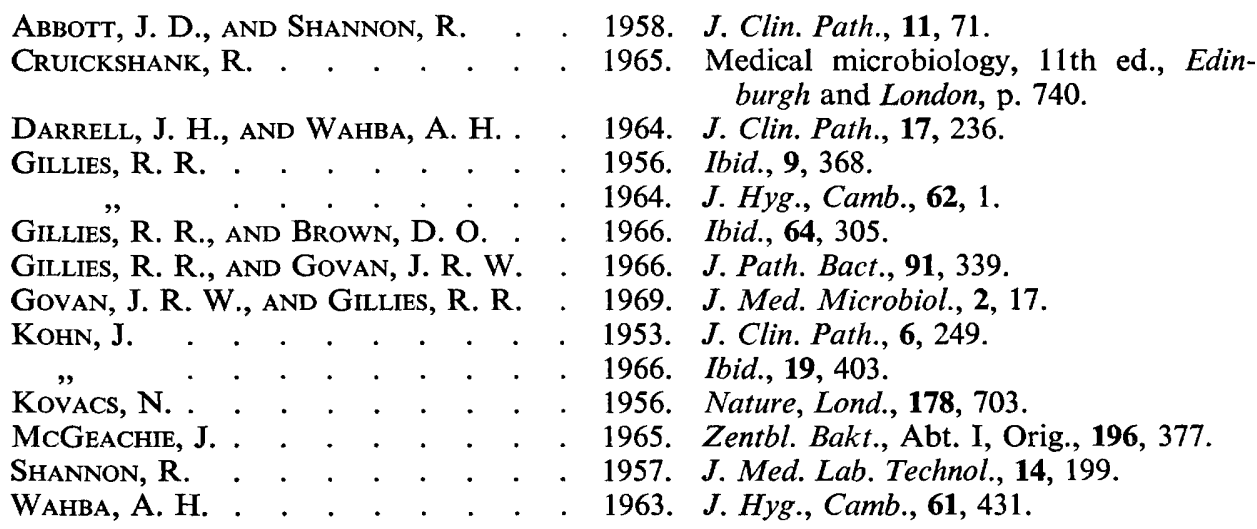

\section{METABOLISM OF THE LIPOPROTEINS OF SERUM BY LEPTOSPIRES: DEGRADATION OF THE TRIGLYCERIDES}

\author{
L. B. Kasărov and Laura Addamiano \\ Laboratori di Microbiologia, Istituto Superiore di Sanità, Rome, Italy
}

Plate XI

ThE studies of Schneiderman et al. (1951), Woratz (1955), Fulton and Spooner (1956), Helprin and Hiatt (1957), Johnson (1958), Ivler (1960), Johnson and Wilson (1960) and Mifuchi, Hosoi and Yanagihara (1961) have shown that the lipids are an important energy source for leptospires and that the major function of the serum as a component of nutrient media for leptospires is to supply lipids. Helprin and Hiatt, Woratz (1957), Ivler (1960), Vaneseltine and Staples (1961), Johnson and Gary (1963), Ellinghausen and McCullough (1965), Shenberg $(1965,1967)$ and Shenberg and van der Hoeden (1961) have proved the role of fatty acids as growth factors for leptospires by showing that they will replace the serum in a nutrient medium. Johnson and Gary showed that one strain belonging to serotype pomona utilised palmitic acid.

Almost all (c. 95 per cent.) of the fatty acids in the serum are found in the lipoproteins as esters of glycerides and cholesterol and as esters or amides of phospholipids. The capacity of the leptospires to utilise the lipoproteins depends on their possession of enzymes catalysing degradation of lipoproteins. The present paper describes observations on the degradation of the triglycerides of the serum by leptospires.

\section{MATERIALS AND METHODS}

Organisms. Observations were made with both parasitic and saprophytic strains of Leptospira taken from the collection of WHO/FAO Leptospira Reference Laboratory, kept in the Istituto Superiore di Sanità in Rome. The parasitic strains were: copenhageni Monika, copenhageni Wijnberg, copenhageni Ratto 67, icterohaemorrhagiae 
Bianchi 1, icterohaemorrhagiae RGA, canicola Hond Utrecht IV, malaya H6, zanoni Zanoni, pomona Pomona, pomona Mezzano I, monjakov Monjakov DVB, grippotyphosa Moskva V, grippotyphosa Mallersdorf, grippotyphosa Vitulina, grippotyphosa RM2, bataviae Pavia 1. The saprophytic strains were: patoc Patoc 1, são paulo São Paulo, doberdò Doberdò 1, basovizza Basovizza, the strain Dindio (not yet classified) and the strain AM20 (not yet classified).

Medium. Korthof medium as modified by Babudieri (1961), distributed in tubes of $20 \mathrm{ml}$, was used for the cultivation of the leptospires. Well-grown cultures, incubated for 10,20 and 30 days at $35^{\circ} \mathrm{C}$, and checked for the absence of bacterial contamination, were used for the experiments.

Serum. Fresh rabbit serum was employed in the experiments. Chylomicrons were removed by filtering the serum, after it had been stored at $4^{\circ} \mathrm{C}$ for $96 \mathrm{hr}$, through a sterilised glass filter, $\mathrm{G} 5 \mathrm{~m}$.

Assay procedure for testing the effect of leptospires on the serum lipoproteins. Three $\mathrm{ml}$ of a well-grown whole culture was added to $1 \mathrm{ml}$ serum. In the controls, the leptospira culture was replaced by the same amount of Korthof medium. After $1-4$ days at $37^{\circ} \mathrm{C}$, both were examined by electrophoresis and extraction of the lipids. Before these tests were done, the culture was examined to confirm that it was free from bacterial contamination.

Total lipid extract. Serum lipids were extracted by Bragdon's method as modified by Jover (1963) and adapted to our purposes. The mixture of rabbit serum and leptospira culture was added to $24 \mathrm{ml}$ of a mixture of two volumes of chloroform and one volume of methanol in an Erlenmeyer flask with a glass stopper. The flask was shaken for $10 \mathrm{~min}$. and $2 \mathrm{ml}$ of distilled water was added. The flask was inverted ten times and the contents were then centrifuged at $2000 \mathrm{~g}$ for $15 \mathrm{~min}$. at $4^{\circ} \mathrm{C}$. Three layers were formed: a lower layer of chloroform containing all the lipids, a middle layer (a disc of tightly packed proteins), and an upper layer of aqueous alcohol. The chloroform layer was transferred and evaporated to dryness in vacuo at $4^{\circ} \mathrm{C}$. The dried extract of lipids was dissolved in $0.2 \mathrm{ml}$ chloroform and transferred to thin-layer plates in amounts of $0.02 \mathrm{ml}$.

Thin-layer chromatography. Thin-layer plates of silica gel $\mathrm{G}$ containing 13 per cent. $\mathrm{CaSO}_{4} \cdot \frac{1}{2} \mathrm{H}_{2} \mathrm{O}$ (E. Merck, Darmstadt, Germany) were prepared with a Desaga applicator. Plates were dried in air, activated at $110^{\circ} \mathrm{C}$ for $1 \mathrm{hr}$ and stored in a desiccator until used. The developing solvent system for separating the neutral lipids was Marinetti's (1962) diethylether-glacial acetic acid- $n$-hexane, $25: 2: 73(\mathrm{v} / \mathrm{v} / \mathrm{v})$. The spots of the neutral lipids were detected by spraying with 15 per cent. perchloric acid and then charring by exposure to $140^{\circ} \mathrm{C}$ for $10 \mathrm{~min}$. The results obtained by chromatography of the extracts on thin-layer plates are illustrated in figs. 1 and 2.

Agar-gel electrophoresis. This was done by the method of Grabar and Burtin (1964). Lipoproteins were stained with sudan black by the method of Uriel and Grabar (1956).

Test for lipase activity. The lipase activity of leptospires was determined by the method of Kasărov (1963) by tests with pork and bovine fat as substrate.

\section{RESULTS}

Saprophytic leptospires. The results of the chromatographic analyses showed that 24 hours' incubation of rabbit serum with a well-grown culture of any of the six saprophytic strains caused the following changes in the lipid content of the serum: (1) a large decrease or complete disappearance of the triglycerides (fig. 1B) and (2) a large increase of the free fatty acids (fig. 1B).

The changes in the composition of the lipoproteins were expressed electrophoretically by a considerable shift of both the $\alpha$ - and $\beta$-lipoprotein bands towards the anode (fig. 3). These changes in the electrophoretic behaviour of the serum lipoproteins were clearly demonstrated with dog (fig. 4) and pig serum as well as rabbit serum. Identical results were obtained with cultures incubated for 10, 20 and 30 days.

Parasitic leptospires. No detectable degradation of triglycerides could be established with the parasitic strains Wijnberg, Ratto 67, Bianchi 1, RGA, Hond Utrecht IV, H6, 


\section{Plate XI}

FIG. 1.-Thin-layer chromatography of neutral lipids extracted from rabbit serum after incubation for $24 \mathrm{hr}$ at $37^{\circ} \mathrm{C}$ with sterile Korthof medium (A) and with a whole culture of the saprophytic leptospira strain São Paulo (B). A chromatogram of oleic acid as control is shown in track C. $\mathrm{CE}=$ Cholesteryl esters; $\mathrm{TG}=$ triglycerides; $\mathrm{FFA}=$ free fatty acids; $\mathrm{CH}=$ cholesterol; $\mathbf{O}=$ origin.

FIG. 2.-Thin-layer chromatography of neutral lipids extracted from rabbit serum after incubation for $96 \mathrm{hr}$ with whole cultures of the parasitic strains Hond Utrecht IV (A) and Mezzano I (C), and with sterile Korthof medium (B).

FIG. 3.-Electrophoresis of rabbit serum after incubation for $24 \mathrm{hr}$ with a culture of the saprophytic strain Patoc 1 (left) and with sterile Korthof medium (right). Anode is at top, cathode at bottom.

FIg. 4.-Electrophoresis of dog serum after incubation for $24 \mathrm{hr}$ with a culture of the saprophytic strain Patoc 1 (left) and with sterile Korthof medium (right). Anode is at top, cathode at bottom. 


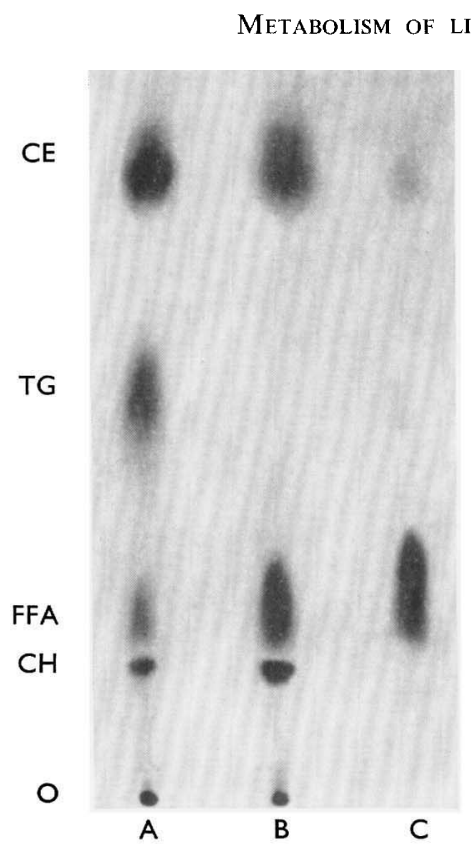

FIG. 1.

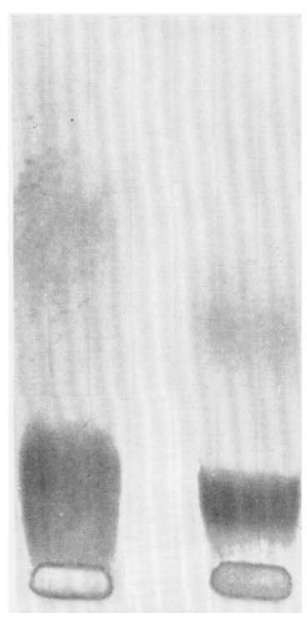

Flg. 3.

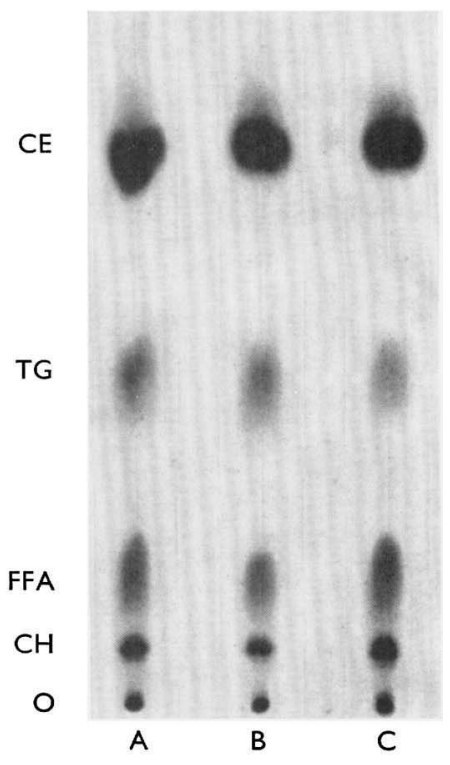

FIG. 2.

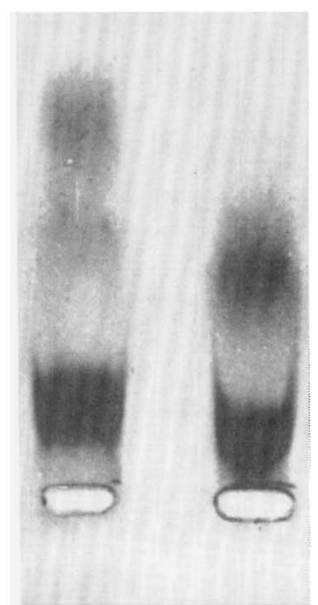

FIG. 4. 
Zanoni, Pomona, Monjakov DVB, Vitulina, RM2, Pavia 1, even when the incubation period was extended to $96 \mathrm{hr}$. With the parasitic strains Monika, Mezzano I, Moskva V, and Mallersdorf, the spot corresponding to the triglycerides was somewhat weaker than in the controls (fig. 2C). All the parasitic leptospires produced an increase in the free fatty acids, but the increase was much less than that produced by the saprophytic strains (fig. $2 \mathrm{~A}$ and $2 \mathrm{C}$ ).

All the leptospires investigated, with the exception of the strain Vitulina, showed some lipase activity with animal fats.

\section{Discussion}

Our experiments show that the saprophytic leptospires degrade the triglycerides of the serum lipoproteins. This degradation is associated with an increase of fatty acids and with changes in the electrophoretic behaviour of the lipoproteins. The changes are similar to those produced in the lipoproteins by the heparin-released lipoprotein lipase described by Korn and Quigley (1957) and Wolff and Wolff (1960). The factor responsible for the increased electrophoretic mobility of the lipoproteins described by us and the increased mobility obtained with lipoprotein-lipase appears to be the production by hydrolysis of larger amounts of fatty acids than can be bound by the serum albumin. According to Gordon (1955), Herbst et al. (1955), Laurell (1955), Mora, Rebeyrotte and Polonovski (1955), Lewin, Ghata and Azerad (1958) and Shafrir (1958), the excess of unesterified higher fatty acids becomes associated with the lipoproteins and has the effect of increasing their negative electrostatic surface charge.

For the present it cannot be stated whether the degradation of the triglycerides of the lipoproteins by the leptospires is catalysed by an enzyme having a mechanism of action like that of the lipoprotein lipase of tissue origin. Hydrolytic splitting of fatty acids of triglycerides is characteristic of the enzyme lipase. The leptospira strains examined, both saprophytic and parasitic, possess a clearly expressed lipase activity. However, the fact that the parasitic leptospires possessing strong lipase activity do not degrade the serum triglycerides or manifest this activity in a weaker form, shows that the degradation of the triglycerides of the serum lipoproteins is not determined by this enzyme. However, the possibility is not excluded that the lipase may participate to some extent in the degradation of the triglycerides. The mechanism of this degradation remains unknown for the present. One possibility is that the triglycerides are first split from the protein-lipid complex, or the bonds holding them in this complex are slackened, and then they are hydrolysed by the lipase. Another possibility is that the structure of the complex, particularly the position of the triglycerides in space, is changed in such a way that the triglycerides become accessible to the lipase. A question needing further study is that of whether the enzyme degrading the triglycerides is a product of the leptospires or is derived from a non-active precursor that is present in the serum and is activated by some product of the leptospires.

The fact that the spot characteristic of the triglycerides was slightly diminished in tests with some of the parasitic leptospires suggests that these strains also possess the ability to degrade the triglycerides of the serum lipoproteins, though the amount of enzyme they produce in the culture medium is very small and difficult to detect by our methods. The slight increase of the free fatty acids by the parasitic leptospires might be explained as a release of free fatty acids from phospholipids of the lipoproteins.

In a subsequent paper we shall report on the degradation of the phospholipids of the serum lipoproteins by leptospires.

\section{SUMMARY}

Incubation of rabbit serum for $24 \mathrm{hr}$ with cultures of six strains of saprophytic leptospires brought about a large decrease, or the complete disappearance, of the triglycerides in the lipoproteins of the serum and a corresponding increase in the serum's content of the free fatty acids. The mechanism underlying the associated changes produced in the electrophoretic pattern of the lipoproteins is discussed in relation to the analogous alteration caused by the lipoprotein lipase. 
Incubation of rabbit serum with cultures of sixteen strains of parasitic leptospires caused little or no change in the amounts of the triglycerides and free fatty acids.

\section{REFERENCES}

Babudieri, B. . . . . . . . . . . 1961. Bull. Wld Hlth Org., 24, 45.

Ellinghausen, H. C., JR, AND 1965. Amer. J. Vet. Res., 26, 45.

McCullough, W. G.

Fulton, J. D., AND Spooner, D. F. . . 1956. Expl Parasit., 5, 154.

Gordon, R. S., JR . . . . . . . . 1955. J. Clin. Invest., 34, 477.

Grabar, P., AND BURtin, P. . . . . 1964. Immuno-electrophoretic analysis, Amsterdam, London and New York, pp. 4-12.

Helprin, J. J., AND Hiatt, C. W. . . 1957. J. Infect. Dis., 100, 136.

Herbst, F. S. M., Lever, W. F., Lyons, 1955. J. Clin. Invest., 34, 581.

M. E., AND HURLEY, N. A.

IVLeR, D. . . . . . . . . . 1960. Bact. Proc., 60, 164.

JoHnson, R. C. . . . . . . . . . 1958. M.S. Thesis, Univ. Wisconsin.

JOHNSON, R. C., AND GARY, N. D. . . 1963. J. Bact., 85, 976.

JoHNSON, R. C., AND WILSON, J. B. . . 1960. Ibid., 80, 406.

JOVER, A.

1963. J. Lipid Res., 4, 228.

KASĂROV, L. B.

1963. Zentbl. Bakt., Abt I, Orig., 188, 98.

Korn, E. D., AND Quigley, J. W., JR . 1957. J. Biol. Chem., 226, 833.

Laurell, S. . . . . . . . . . 1955. Scand. J. Clin. Lab. Invest., 7, 28.

Lewin, J., Ghata, J., And Azerad, E. . 1958. Pathol. Biol., Paris, 6, 1567.

MARINETt, G. V. . . . . . . . 1962. J. Lipid Res., 3, 1.

MifUChI, I., HosoI, M., AND YaNAGI- 1961. Jap.J. Microbiol., 5, 215. HARA, Y.

Mora, R., Rebeyrotte, P., and Pol- 1955. Bull. Soc. Chim. biol., 37, 957. ONOVSKI, J.

Schneiderman, A., Greene, M. R., 1951. Proc. Soc. Exp. Biol. Med., 78, 777.

SCHIEler, L., MCClure, L. E., AND DuNN, M. S.

SHAFRIR, E. .

1958. J. Clin. Invest., 37, 1775.

SHENBERG, ESTHER .

1965. Ph.D. Thesis, Hebrew University, Jerusalem.

" . . . . . . . . 1967. J. Bact., 93, 1598.

Shenderg, Esther, AND VAN Der Hoeden, 1961. Bull. Res. Coun. Israel, sect. I, 9E, p. 116. J.

URIEL, J., AND GRABar, P.

1956. Bull. Soc. Chim. biol., 38, 1253.

VANeseltine, W. P., AND Staples, Sarah A.

WOLFF, R., AND WOLFF, J.

1961. J. Infect. Dis., 108, 262.

WORATZ, $\mathbf{H}$.

1960. Pathol. Biol., Paris, 8, 1473.

1955. Zentbl. Bakt., Abt I, Orig., 162, 106.

1957. Ibid., 169, 269. 